Crop Breeding and Applied Biotechnology 14: 108-115 2014

Brazilian Society of Plant Breeding. Printed in Brazil

\title{
ARTICLE
}

http://dx.doi.org/10.1590/1984-70332014v14n2a19

\section{Micropropagation and callogenesis in Mandevilla guanabarica (Apocynaceae), an endemic plant from Brazil}

\author{
Sandra Zorat Cordeiro ${ }^{1 *}$, Naomi Kato Simas ${ }^{2}$, Anaize Borges Henriques ${ }^{3}$ and Alice Sato ${ }^{4}$
}

Received 23 April 2013

Accepted 29 January 2014

\begin{abstract}
Mandevilla guanabarica is an endemic plant from Brazil, with pharmacological and ornamental potential, both unexplored. This study established the best culture medium for in vitro plant maintenance, efficient protocol for its regeneration, and callogenesis from different explants excised from in vitro-grown plants. Woody plant medium with double boron concentration (WPM ${ }_{B}$ ) plus 2.27 $\mu M$ thidiazuron or $0.49 \mu M$ 2-isopentenyladenine provided multiplication rates higher than 1:6. Shoots were 100\% rooted on WPM $M_{B}$. After acclimatization, plants showed $83 \%$ survival. For callogenesis, the use of MS media supplemented with high concentrations of picloram or 2,4-dichlorophenoxyacetic acid produced, respectively, friable or compact non-morphogenic calluses from different types of explants. This micropropagation protocol allows the production of seedlings of $\mathrm{M}$. guanabarica for ornamental or commercial uses, and for conservation purposes; calluses can be used to establish suspension cultures in prospecting for bioactive compounds.
\end{abstract}

Key words: Morphogenesis, tissue culture, plant regeneration, callus induction.

\section{INTRODUCTION}

Mandevilla Lindley is the largest Neotropical genus of Apocynoideae (Apocynaceae) subfamily, and at least 70 species have been reported for Brazil (Sales et al. 2006). The landscape and ornamental potential of this genus is widely recognized and exploited in Europe and the United States, through culture and development of new varieties (EPO 2013). Members of Mandevilla are also highly interesting for their ethnobotanical uses: several species are used as medicinal and spiritual aids by indigenous people throughout the Neotropical region (Schultes 1979, Adams et al. 2007, Bussmann et al. 2011). The pharmacological potential of Mandevilla is confirmed by results obtained in many studies on M. velutina (Mart.) Woodson and M. illustris (Vell.) Woodson. These species have an underground system that is widely used in folk medicine in the form of infusions or alcoholic extracts, against inflammation and snakebite (Calixto et al. 1985). For optimizing the production of secondary metabolites with pharmacological properties from the underground system of Mandevilla species, micropropagation protocols have been established, using in vitro culture techniques (Handro et al. 1988, Biondo et al. 2004, Biondo et al. 2007).

According to Pilatti et al. (2011), the prioritization of endemic, threatened species, and the habitats where they live is a crucial point of conservation actions, particularly in areas with rich endemic floras. In vitro culture techniques are a way of ex situ conservation, and have been used to secure and protect the native plant species, where new species with virtually unknown ornamental and pharmacological potential are continually being discovered.

Mandevilla guanabarica Casaretto ex. M.F. Salles, Kinoshita-Gouvêa and A. Simões (Sales et al. 2006) is an endemic species of the Atlantic Forest. It is a liana, with slender, latescent, twining, and densely leafy lateral branches. Its distribution is restricted to the edges of shrub thickets in restingas of the states of Rio de Janeiro and Espírito Santo. Although it is not officially at risk of extinction, $M$. guanabarica is restricted to restingas, many of which have undergone intense human impact due to land speculation and extractive predatory practices. Micropropagation and in vitro conservation of $M$. guanabarica are strategies that

\footnotetext{
${ }^{1}$ Universidade Federal do Rio de Janeiro (UFRJ), Av. Carlos Chagas Filho, 373, Sala K2-32, 21.941-902, Rio de Janeiro, RJ, Brazil. *E-mail: sandrazorat@hotmail.com ${ }^{2}$ UFRJ, Faculdade de Farmácia, Departamento de Produtos Naturais e Alimentos, Av. Carlos Chagas Filho, 373, Sala A2-16, 21.941-902, Rio de Janeiro, RJ, Brazil

${ }^{3}$ UFRJ, Instituto de Biologia, Laboratório de Fisiologia do Desenvolvimento Vegetal, Av. Carlos Chagas Filho, 373, Sala A1-122, 21.941-902, Rio de Janeiro, RJ, Brazil ${ }^{4}$ Universidade Federal do Estado do Rio de Janeiro (UNIRIO), Departamento de Botânica, Laboratório de Cultura de Tecidos Vegetais, Av. Pasteur, 458, Sala 414, 22.290-040, Rio de Janeiro, RJ, Brazil
} 
allow its sustainable use and conserve its genetic diversity, provide protection against predatory exploitation in its natural habitats, and still allow investigations about its phytochemical characterization, through callogenesis.

The objectives of this study were i) to establish an efficient protocol for regeneration of $M$. guanabarica, either for production of seedlings for ornamental purposes, or for assays for substances of pharmacological interest, and ii) callus induction from different explants excised from in vitro-grown plants to use in prospecting for bioactive compounds.

\section{MATERIAL AND METHODS}

\section{Plant material}

Mandevilla guanabarica fruits and branches were collected in the Maricá Environmental Protection Area (22 $52^{\prime}$ to $22^{\circ} 54^{\prime} \mathrm{S}$ and $42^{\circ} 48^{\prime}$ to $42^{\circ} 54^{\prime} \mathrm{W}$ ) in the municipality of Maricá, RJ. Authorization to collect was granted by INEA (Instituto Estadual do Ambiente) and IBAMA (Instituto Brasileiro do Meio Ambiente e dos Recursos Naturais Renováveis). Vouchers are deposited at the Herbarium Bradeanum (HB), under accession numbers HB 93039 and 93041.

\section{Culture media and conditions}

Basal media consisted of LS (Linsmaier and Skoog 1965), WPM (Lloyd and McCown 1980) or MS (Murashige and Skoog 1962) salts, supplemented respectively with LS, MS or WPM vitamins and $2 \%, 2 \%$ or $3 \%$ sucrose $(\mathrm{w} / \mathrm{v})$, and solidified with $0.75 \%$ agar $(\mathrm{w} / \mathrm{v})$. Other variants of MS and WPM media were supplemented with twice the original boron concentration, termed $\mathrm{MS}_{\mathrm{B}}$ and $\mathrm{WPM}_{\mathrm{B}}$, respectively. To shoot production, different concentrations of the plant growth regulators were added to one of the basal media: 0 , 4.44 or $8.87 \mu \mathrm{M}$ benzyladenine (BA); $0,4.65$ or $9.29 \mu \mathrm{M}$ kinetin (KIN); 0, 4.56 or $9.12 \mu \mathrm{M}$ zeatin (Zea); 0, 0.49, 2.46, 4.92, 14.76, $24.61 \mu \mathrm{M}$ 2-isopentenyladenine (2-iP); or $0,0.45,2.27,4.54,13.62$ or $22.71 \mu \mathrm{M}$ thidiazuron (TDZ). For callus induction, 20 or $40 \mu \mathrm{M}$ of picloram (PIC), or 2,4-dichlorophenoxyacetic acid (2,4-D) were added to MS medium. The $\mathrm{pH}$ of all media was adjusted to 5.8 , and the liquid medium was dispensed in glass tubes $(2.0 \times 15.0 \mathrm{~cm})$ for seed germination, or in glass bottles $(7.5 \times 13.5 \mathrm{~cm})$ for the establishment of culture, shoot production, rooting, or callus induction, and autoclaved for $15 \mathrm{~min}$ at $121^{\circ} \mathrm{C} / 1.0$ $\mathrm{atm}$. All cultures were maintained in a growth room at $25 \pm 1$ ${ }^{\circ} \mathrm{C}$, under a $16 \mathrm{~h}$ photoperiod with an irradiance of $23 \mu \mathrm{mol}$ $\mathrm{m}^{-2} \mathrm{~s}^{-1}$ provided by daylight fluorescent lamps.

\section{Culture establishment}

Seeds were obtained after the dehiscence of fruits. Tuft of trichomes, which assist in seed dispersal, was removed by hand, and seeds were surface-sterilized, under agitation, with $10 \%(\mathrm{v} / \mathrm{v})$ commercial detergent for $10 \mathrm{~min}, 70 \%(\mathrm{v} / \mathrm{v})$ ethanol for $10 \mathrm{~min}$, and $30 \%$ (v/v) sodium hypochlorite for $5 \mathrm{~min}$, and then washed three times with sterile distilled water. In laminar air flow, disinfested seeds were inoculated into glass tubes containing $10 \mathrm{ml}$ of MS medium, and were maintained in a growth room for 60 days. After this period, plantlets obtained were used as a source of explants for the experiments.

\section{Establishment of culture medium}

Isolated nodal segments $(1.0 \mathrm{~cm}$ long) were inoculated into glass bottles with $50 \mathrm{~mL}$ of LS, MS, $\mathrm{MS}_{\mathrm{B}}$, WPM or $\mathrm{WPM}_{\mathrm{B}}$ medium and maintained in a growth room for two months. The experimental design was fully randomized, with 6 replicates per treatment; each replicate consisted of a bottle of 5 nodal segments $(\mathrm{n}=30)$. After this period, plant development was evaluated regarding multiplication rate, and root or callus formation.

\section{Shoot production}

The culture medium which presented the best results for multiplication rate $\left(\mathrm{WPM}_{\mathrm{B}}\right)$ was used in the experiment on shoot production. Isolated nodal segments (1.0 cm long) were inoculated into glass bottles with $50 \mathrm{ml}$ of $\mathrm{WPM}_{B}$ medium, supplemented with the concentrations mentioned above for BA, KIN, Zea, 2-iP and TDZ. The experimental design was fully randomized, consisting of 10 replicates per treatment; each replicate consisted of a bottle of 3 nodal segments $(n=30$ / treatment). All cultures were maintained in a growth room for two months, and after this period, shoot development was evaluated with respect to the number of nodal segments per explant (multiplication rate), and root or callus formation.

\section{Rooting}

Shoots $(3-4 \mathrm{~cm})$ were excised from plants grown in the culture medium which were most efficient in inducing buds, and placed in glass bottles with $50 \mathrm{ml}$ of $\mathrm{WPM}_{\mathrm{B}}$, according to the results described in the section Establishment of culture medium. Cultures were maintained in a growth room for three months.

\section{Acclimatization}

In vitro-grown plants with roots and/or callus, shoot development, and more than $4.0 \mathrm{~cm}$ high were removed 
from the glass bottles, washed in tap water to remove excess medium, and carefully transferred to plastic pots containing autoclaved vermiculite. Pots were placed in a plastic box covered with plastic film, for acclimatization in a greenhouse at a temperature of $28 \pm 2{ }^{\circ} \mathrm{C}$. During the course of one month, the plastic film cover was removed gradually; by the end of the month, pots were uncovered. Survival rate was evaluated after two months.

\section{Callus induction}

Several types of explants were excised from plantlets grown in vitro: apical meristems $(5 \mathrm{~mm})$, leaves $\left(1 \mathrm{~cm}^{2}\right)$, nodal segments, internodal segments, and roots $(1 \mathrm{~cm})$, and epicotyl and hypocotyl $(0.5 \mathrm{~cm})$. These explants were inoculated into glass bottles with $50 \mathrm{ml}$ of MS medium supplemented with two different concentrations of 2,4-D or PIC $(20,40 \mu \mathrm{M})$, and maintained in a growth room under light (16h photoperiod) or in darkness. The experimental design was fully randomized, with 5 replicates per treatment and type of explant; each replicate consisted of a bottle of 2 explants ( $n=10 /$ treatment). Cultures were maintained in a growth room for two months, and after this period, they were evaluated regarding the type of callus developed (friable or mucilaginous, non-organogenic or embryogenic), and biomass accumulation, based on fresh and dry weights. Dry weights were determined after drying at $70 \pm 2{ }^{\circ} \mathrm{C}$ for $24 \mathrm{~h}$ to constant weight.

\section{Statistics}

Data were subjected to analysis of variance (ANOVA), and means were compared with the Tukey-Kramer test at $0.05 \%$ significance level, using the software GraphPad InStat v. 3.01 and Sigma Plot ${ }^{\mathrm{TM}}$ for Windows, version 11.0.

\section{RESULTS AND DISCUSSION}

The disinfestation method applied to seeds of M. guanabarica provided $100 \%$ uncontaminated seeds. After two months of culture, plantlets showed fully development of roots and shoots. The establishment of a protocol for micropropagation from seeds allows the maintenance of genetic variability, which is essential for germplasm conservation, particularly in the case of endangered species. Other advantages of seeds are the ability to obtain a large number of explants from plantlets germinated in vitro, young tissues that are highly responsive to growth regulators, and lack of need for the difficult process of disinfestation of explants from woody plants from the field, or for phenolic oxidation, which can negatively affect the development of the explant in vitro (Bonga 1982, Grattapaglia and Machado 1998).
Multiplication rate and rooting of plants cultivated on LS, MS, $\mathrm{MS}_{\mathrm{B}}$, WPM and $\mathrm{WPM}_{\mathrm{B}}$ media are shown in Table 1. All media promoted the development of pre-existing meristems. LS, MS, $\mathrm{MS}_{\mathrm{B}}$ and WPM media induced multiplication rates of $1: 1.8$ to $1: 2.2$ and rooting of 51 to $70 \%$, which did not differ significantly among each other. In plants cultivated on $\mathrm{MS}$ and $\mathrm{MS}_{\mathrm{B}}$, leaf blade was smaller, and shoot apex died in $83 \%$ of the plants. $\mathrm{WPM}_{\mathrm{B}}$ (Figure 1a) was the most effective for shoots, with a multiplication rate of 1:3.5 and $100 \%$ rooting. $\mathrm{MS}_{\mathrm{B}}$ and $\mathrm{WPM}_{\mathrm{B}}$ were used since apical death occurred in approximately $70 \%$ of plantlets grown for two months on MS medium. Although the symptoms of boron deficiency are related to species and plant age, the characteristic symptom is observed mainly in shoots since boron deficiency limits leaf expansion, resulting in small leaves, necrosis and death of young leaves and terminal buds, and consequent loss of apical dominance, forming a highly branched plant (Dell and Huang 1997).

Supplementation of WPM medium with boron was effective for in vitro development of M. guanabarica. This medium, indicated for woody plants, has lower concentration of nutrients than the salt composition of MS, with $25 \%$ of the nitrate and ammonia contained in LS and MS, but with high concentrations of potassium and sulfate (Linsmaier and Skoog 1965). Studies on the micropropagation of other Mandevilla species obtained positive results with LS medium

Table 1. Multiplication rate and rooting of nodal segments of Mandevilla guanabarica cultured on different media, after two months of culture

\begin{tabular}{lllll}
\hline Culture medium & Multiplication rate $^{1}$ & \multicolumn{2}{c}{$\begin{array}{c}\text { Rooting }^{1} \\
(\%)\end{array}$} \\
\hline $\mathrm{LS}$ & $1.92 \pm 0.86$ & $\mathrm{~b}$ & 58 & $\mathrm{~b}$ \\
$\mathrm{MS}$ & $1.88 \pm 0.83$ & $\mathrm{~b}$ & 51 & $\mathrm{~b}$ \\
$\mathrm{MS}_{\mathrm{B}}$ & $2.04 \pm 0.88$ & $\mathrm{~b}$ & 70 & $\mathrm{~b}$ \\
$\mathrm{WPM}$ & $2.23 \pm 1.52$ & $\mathrm{~b}$ & 64 & $\mathrm{~b}$ \\
$\mathrm{WPM}_{\mathrm{B}}$ & $3.52 \pm 1.75$ & $\mathrm{a}$ & 100 & $\mathrm{a}$ \\
\hline
\end{tabular}

Different letters, in each column, indicate statistical differences by the Tukey-Kramer test $(\mathrm{p}<0.05)$

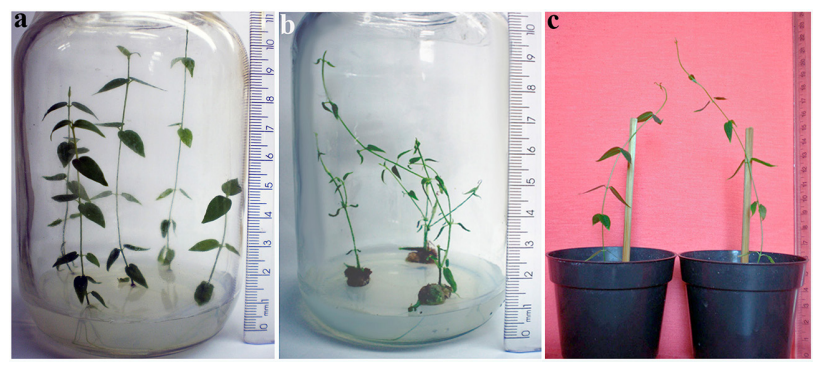

Figure 1. Plants of Mandevilla guanabarica in vitro and acclimatized: a - plants developed from nodal segments cultivated on $\mathrm{WPM}_{\mathrm{B}}$ medium (after two months); $\mathbf{b}$ - plants developed from nodal segments cultivated on $\mathrm{WPM}_{\mathrm{B}}$ medium $+0.49 \mu \mathrm{M} 2$-iP (after two months); $\mathbf{c}$-acclimatized plants in plastic pots containing vermiculite, after two months of acclimatization. 
(Handro et al. 1988) and MS medium with the concentration of salts reduced to one-third (Biondo et al. 2004, Biondo et al. 2007). Similarly superior results with diluted media were obtained here for M. guanabarica.

After two months of culture, all plants grown on WPM medium supplemented with cytokinin showed shoot production by direct organogenesis, via the development of preexisting meristems, with basal and friable calluses and without roots. Plants cultivated on $\mathrm{WPM}_{\mathrm{B}}$ without growth regulators showed $100 \%$ rooting, and calluses in only $30 \%$ of them. All media supplemented with cytokinin allowed the development of friable basal calluses (Table 2), and induced changes in the morphology of leaves, making them small and tapered. Plants cultured on $\mathrm{WPM}_{\mathrm{B}}$ supplemented with 2-iP at low concentrations $(0.49$ and $2.46 \mu \mathrm{M})$ also showed high multiplication rate, above 1:6 (Figure 2a); plants cultured on $\mathrm{WPM}_{\mathrm{B}}$ supplemented with 2.27 or $4.54 \mu \mathrm{M}$ TDZ showed the highest multiplication rates, on the order of 1:7.5 (Figure 2b). Plants cultured on media supplemented with 2-iP (Figure 1b), although they showed a lower multiplication rate than plants cultured on media supplemented with TDZ, presented less alteration in leaf morphology; thus, 2-iP was considered the most effective plant growth regulator for regeneration of $M$. guanabarica.

Shoots were rooted from cultures on $\mathrm{WPM}_{\mathrm{B}}$ medium, the best for this purpose as previously evaluated in the section Establishment of culture medium. After three months, all plants showed rooting by indirect organogenesis, with roots arising from the basal callus or from a large thickening at the base of the stem. Rooting was not affected by the absence of growth regulators in the medium, which allowed these plants to acclimatize. Two months after transfer to soil, the ex vitro survival rate was $83 \%$, and the aerial parts were fully developed (Figure 1c).

Shoot production by direct organogenesis via the development of preexisting meristems was observed in all treatments with cytokinins. TDZ cytokinins, which are a potent regulator and more active than BA and Zea, and 2-iP have been recommended for micropropagation in order to induce axillary bud development and shoot elongation (Pereira-Netto 1996, Biondo et al. 2007). High rates of shoot multiplication were obtained, by direct organogenesis, with the same concentrations used here, 0.49 and $2.46 \mu \mathrm{M} 2-\mathrm{iP}$ for M. illustris (Biondo et al. 2004), and for other species of Apocynaceae, such as Holarrhena antidysenterica, with $15 \mu \mathrm{M}$ 2-iP (Raha and Roy 2001). Although BA has not been effective in shoot production for $M$. guanabarica, this regulator in the range of 4.44 to $8.87 \mu \mathrm{M}$ promoted multiplication rates of 1:21 for $M$. moricandiana (Cordeiro et al. 2012).

Table 2. Effect of growth regulators on in vitro nodal segments of Mandevilla guanabarica, after two months of culture

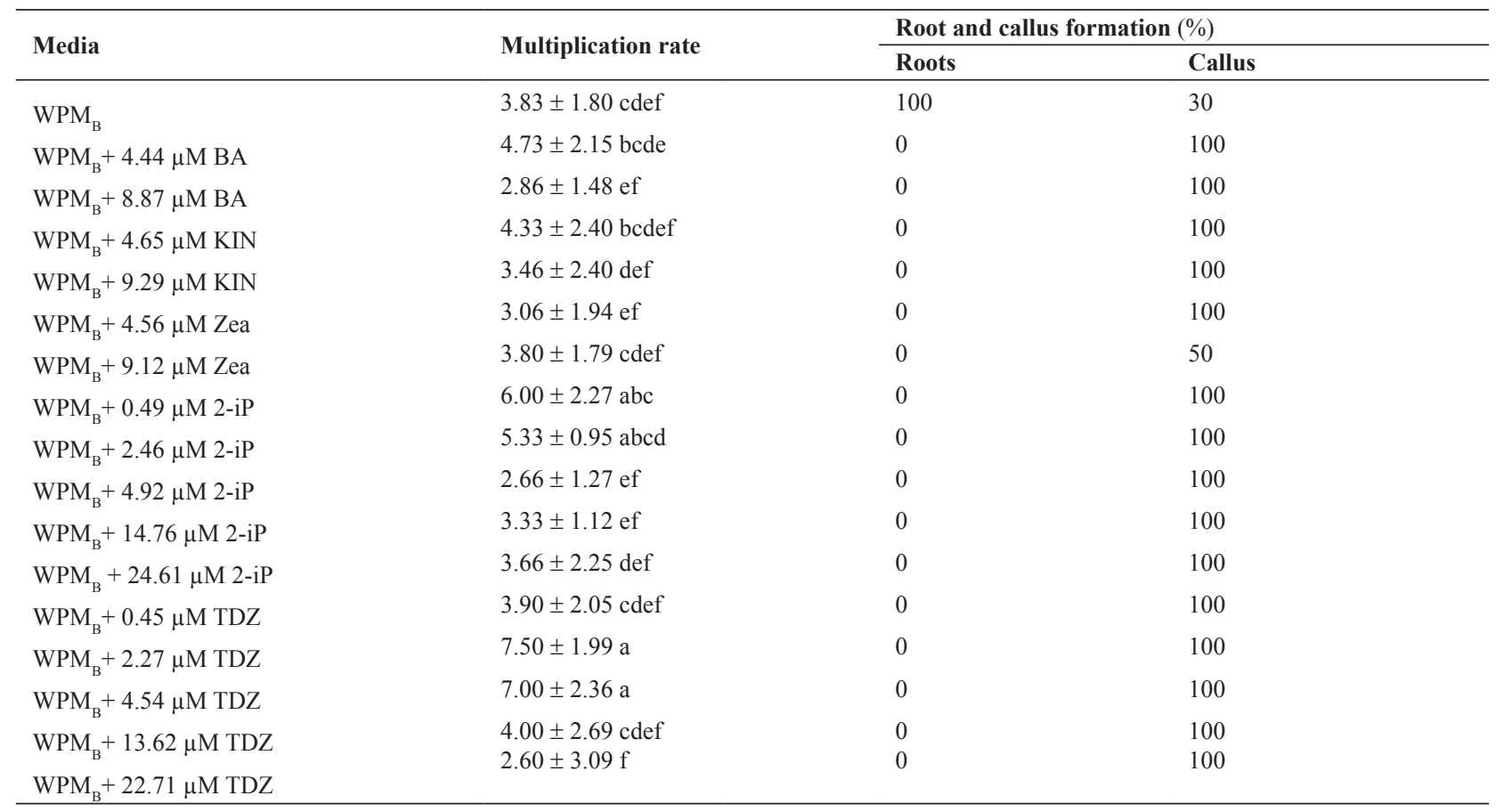

Different letters in multiplication rate column, indicate statistical differences by the Tukey-Kramer test $(\mathrm{p}<0.05)$. 

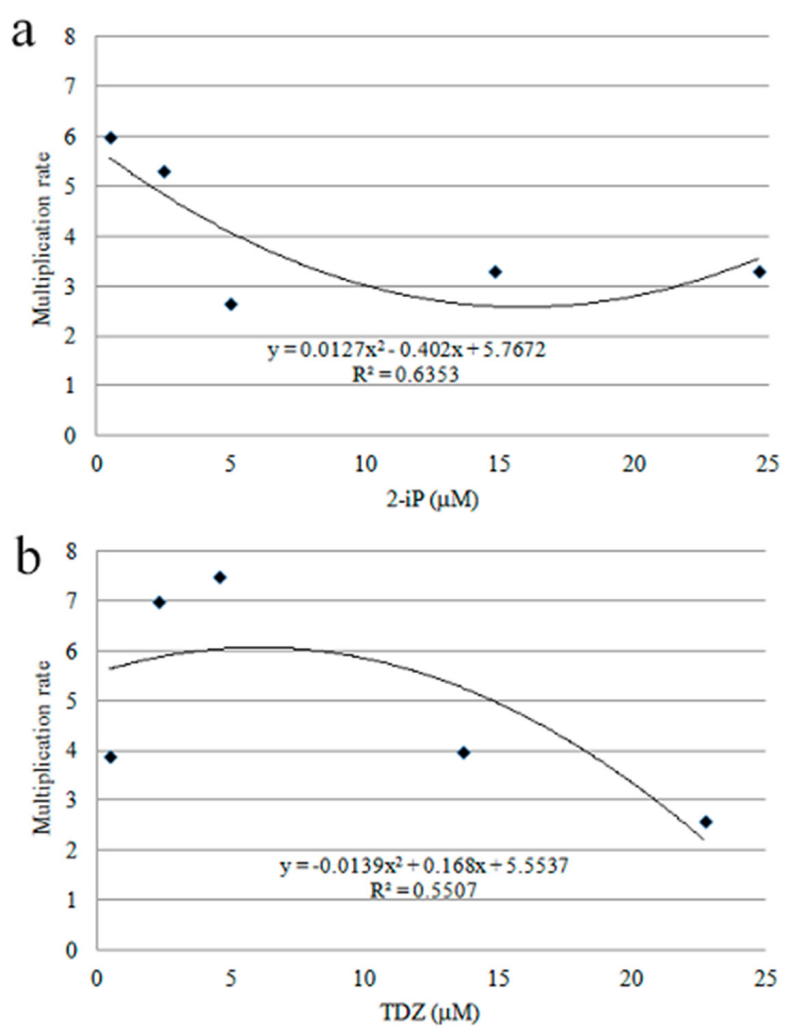

Figure 2. Multiplication rate of nodal segments of Mandevilla guanabarica after two months of culture on $W_{P M}$ medium supplemented with different citokinins: $\mathbf{a}-\mathrm{WPM}_{\mathrm{B}}$ supplemented with different concentrations of 2-iP; $\mathbf{b}-\mathrm{WPM}_{\mathrm{B}}$ supplemented with different concentrations of TDZ.

Other studies have been successful in producing shoots of Mandevilla, although via indirect organogenesis from friable and basal calluses. With M. velutina, multiple shoots were obtained using combinations of BA-NAA (Handro et al. 1988) or BA in the range of 0.44 to $4.44 \mu \mathrm{M}$, with a maximum multiplication rate of 1:6.7; Zea, TDZ and 2-iP were not effective in producing shoots of this species (Biondo et al. 2007).

In these studies with Mandevilla, rooting was improved by the addition of auxins to the culture medium; the best results were obtained with NAA and IBA for M. illustris and M. velutina (Handro et al. 1988, Biondo et al. 2007), and IAA and IBA for M. moricandiana (Cordeiro et al. 2012). For M. guanabarica, $\mathrm{WPM}_{\mathrm{B}}$ without plant growth regulators allowed $100 \%$ rooting, which was fundamental for successful acclimatization. According to Handro et al. (1988), Biondo et al. (2004) and Biondo et al. (2007), plants with an underground system composed by a xylopodium or tuberous roots need more studies of in vitro rooting, which is fundamental for successful micropropagation.

Regarding the callogenesis, all explants grown under light developed non-morphogenic calluses, which differed in type and color according to the growth regulator, regardless of the concentration or type of explant. The calluses developed in 2,4-D were compact and colored green to brown (Figures $3 \mathrm{a}$ and $3 \mathrm{~b}$ ), while those developed in PIC were friable and yellowish-white (Figures $3 \mathrm{c}$ and $3 \mathrm{~d}$ ). All explants maintained in the dark, except the root explants cultured with 2,4-D, showed senescence after two to three weeks of culture. After two months in a growth room, regardless of the concentration of the growth regulator, calluses developed from roots and maintained in the dark were friable and brown, and showed intense development of roots with negative geotropism. Regardless of the light conditions, type of explant or growth regulator, none of the calluses developed somatic embryos.

Only calluses cultured under light were evaluated about biomass accumulation since those kept in the dark had senesced. The accumulation of fresh and dry biomass of calluses was evaluated statistically and the results did not allow determination of a culture medium or explant more efficient in promoting callus, since the obtained data were not statistically significant. The explants cultured in the presence of 2,4-D or PIC developed calluses, and although each type of explant had a standard size, there was wide variation in the size of the developed calluses, which caused the high standard deviation observed in all the samples (Figure 4). However, statistical analysis just enabled to state that roots grown in medium supplemented with $40 \mathrm{mM}$ PIC did not promote callus formation or accumulation of biomass as observed for other types of explants.
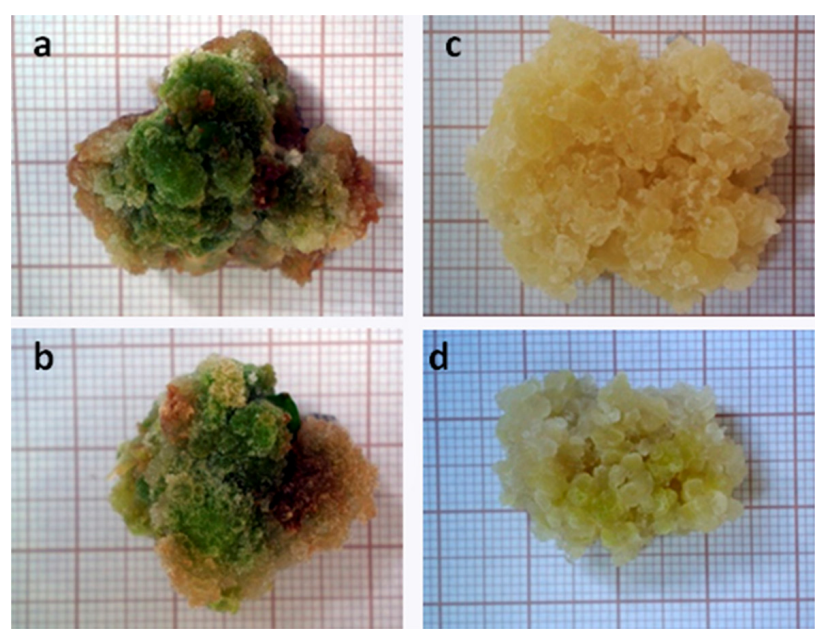

Figure 3. Aspect of calluses developed from explants of Mandevilla guanabarica cultivated on MS medium after two months of culture, under light: a. hypocotyl segment cultivated on MS $+20 \mu \mathrm{M} 2,4-\mathrm{D}$; b. leaf segment cultivated on MS $+40 \mu \mathrm{M} 2,4-\mathrm{D}$; c. epicotyl segment cultivated on $\mathrm{MS}+20 \mu \mathrm{M}$ PIC; d. internodal segment cultivated on MS + $40 \mu \mathrm{M}$ PIC. 

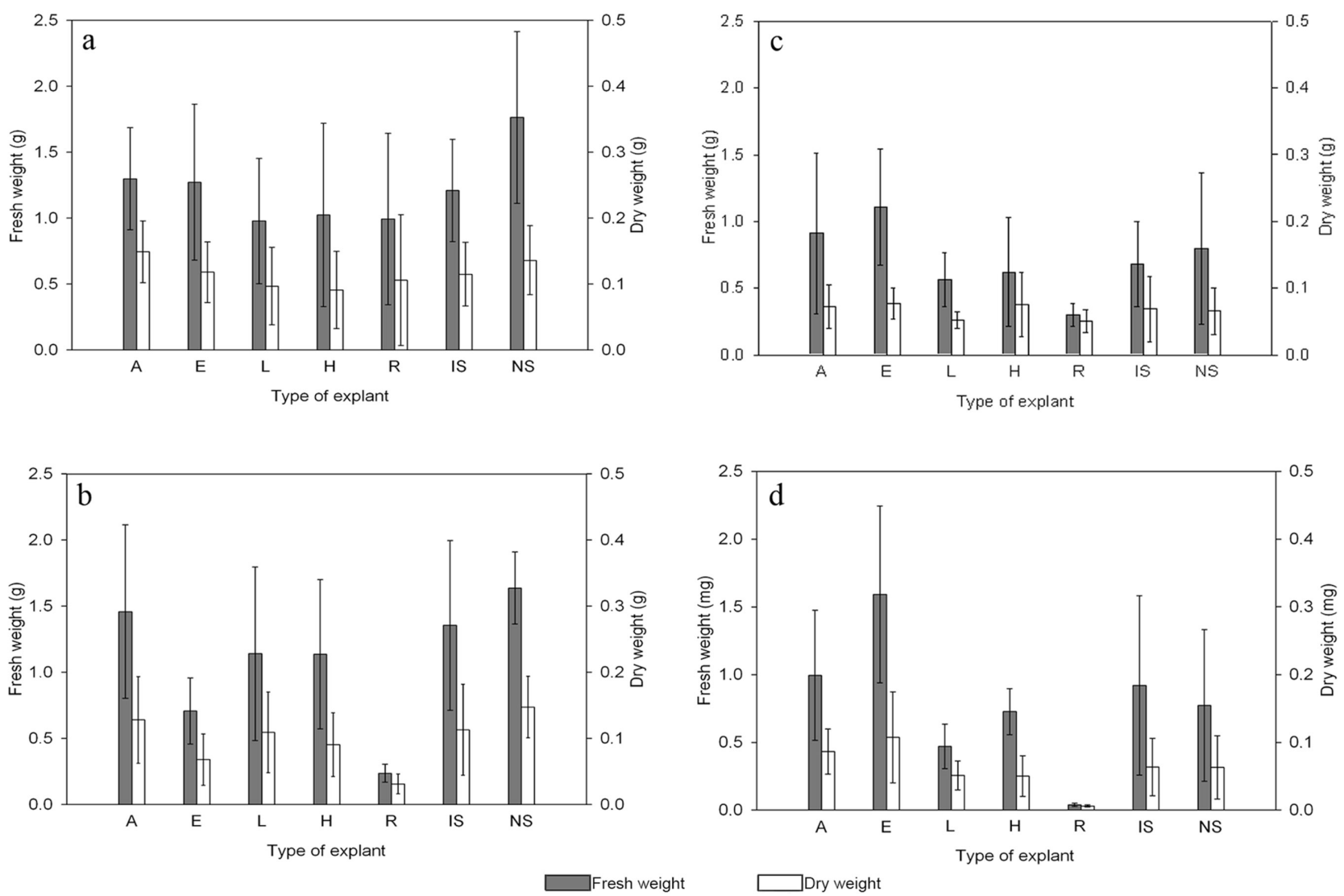

Figure 4. Biomass accumulation ( $\mathrm{g}$ ) of calluses derived from explants of Mandevilla guanabarica, inoculated on MS medium supplemented with different concentrations of 2,4-D or PIC, after two months of culture under light. a. $20 \mu \mathrm{M} 2,4-\mathrm{D}$; b. $40 \mu \mathrm{M} 2,4-\mathrm{D}$; c. $20 \mu \mathrm{M}$ PIC; d. $40 \mu \mathrm{M}$ PIC. Type of explant: A - apical meristems, E - epicotyl, L - leaf, H - hypocotyl, R - root, IS - internodal segment, and NS - nodal segment.

According to Guerra et al. (1999), media with a high concentration of salts, such as MS, in combination with high concentrations of auxins, have shown positive effects on the growth and development of calluses and somatic embryos. Light is also an important factor in somatic embryogenesis, and somatic embryos are generally induced in darkness. For M. guanabarica, auxins promoted calluses without regeneration of somatic embryos.

In the only reference to the use of 2,4-D in Mandevilla, Handro et al. (1988) found that this growth regulator was more efficient for growth of subcultured calluses than $\alpha$-naphthalene-acetic acid and indole-3-acetic acid. Somatic embryogenesis in Mandevilla has not been studied. Most studies of somatic embryogenesis in members of Apocynaceae have treated aspects of the production of secondary metabolites by embryogenic calluses of medicinal plants, where BA-NAA combinations promoted somatic embryogenesis from root segments of Catharanthus roseus (Aslam et al. 2010), Rauvolfia micrantha (Sudha and Seeni 2006) and Tylophora indica (Sahai et al. 2010).

The micropropagation protocol established here is efficient for the production of M. guanabarica plants since it utilizes low concentrations of 2-iP in WPM supplemented with boron for plant regeneration and no growth regulator for rooting, and $83 \%$ of the plants successfully acclimatized. Produced plants can be used for ornamental purposes and for assays for substances of pharmacological interest, without affecting the natural populations of this endangered species. Since the protocol was developed from seeds, the maintenance of the genetic variability of the explants further allows them to be used for in vitro conservation of germplasm. Further optimization is needed for effectively promote somatic embryogenesis in M. guanabarica. Although embryogenic calluses were not produced, different growth regulators led to the formation of calluses with different characteristics, with intense cell proliferation and biomass accumulation, which makes them suitable for the establishment of cell-suspension cultures, for use in studies of the 
pharmacological potential of Mandevilla guanabarica.

\section{ACKNOWLEDGMENTS}

The authors thank CAPES (Coordenação de Aperfeiçoamento de Pessoal de Nível Superior) for doctoral scholarship for the first author, PBV-UFRJ (Programa de Pós-graduação em Biotecnologia Vegetal - UFRJ) and FAPERJ (Fundação de Amparo à Pesquisa do Estado do Rio de Janeiro) for financial support, taxonomists Prof. Dr. Jorge Fontella Pereira (Museu Nacional - UFRJ), MSc. Marcelo Fraga Castilhiori and Inaldo do Espírito Santo (Herbarium Bradeanum) for species identification, UNIRIO (Universidade Federal do Estado do Rio de Janeiro) for providing transportation to the collection areas, and IBAMA (Instituto Brasileiro do Meio Ambiente e dos Recursos Naturais Renováveis) and INEA (Instituto Estadual do Ambiente) for authorization to collect.

\section{Micropropagação e calogênesis em Mandevilla guanabarica (Apocynaceae), uma planta endêmica do Brasil}

Resumo - Mandevilla guanabarica é uma planta endêmica do Brasil, com potencial farmacológico e ornamental inexplorados. Este estudo estabeleceu um eficiente meio de cultura para manutenção da planta in vitro e eficazes protocolos de regeneração e calogênese a partir de diferentes explantes. O meio para plantas lenhosas suplementado com o dobro da concentração de boro (WPM $M_{B}$ e com 2,27 $\mu \mathrm{M}$ de thidiazuron ou 0,49 $\mu \mathrm{M}$ 2-isopenteniladenina proporcionou taxas de multiplicação maiores que 1:6. Os brotos foram 100\% enraizados em $W P M_{B,}$ com $83 \%$ de sobrevivência após aclimatização. Na calogênese, o meio MS suplementado com altas concentrações de picloram ou ácido 2,4-diclorofenoxiacético produziu, respectivamente, calos não morfogênicos friáveis ou compactos. Este protocolo de micropropagação permite a produção de mudas de M. guanabarica para uso ornamental, comercial e com finalidades de conservação; os calos podem ser utilizados para o estabelecimento de culturas em suspensão na prospecção de compostos bioativos.

Palavras-chave: Morfogênese, cultura de tecidos, regeneração vegetal, indução de calos.

\section{REFERENCES}

Adams M, Gmünder F and Hamburger M (2007) brain Plants traditionally used in age related disorders - A survey of ethnobotanical literature. Journal of Ethnopharmacology 113: 363-381.

Aslam J, Mujib A, Fatima Z and Sharma MP (2010) Variations in vinblastine production at different stages of somatic embryogenesis, embryo, and field-grown plantlets of Catharanthus roseus L. (G) Don, as revealed by HPLC. In vitro Cellular and Developmental Biology - Plant 46: 348-353.

Biondo R, Soares AM, Bertoni BW, França SC and Pereira MAS (2004) Direct organogenesis of Mandevilla illustris (Vell.) Woodson and effects of its aqueous extract on the enzymatic and toxic activities Crotalus durissus terrificus snake venom. Plant Cell Reports 22: 549-552.

Biondo R, Souza AV, Bertoni BW, Soares AM, França SC and Pereira MAS (2007) Micropropagation, seed propagation and germplasm bank of Mandevilla velutina (Mart.) Woodson. Scientia Agricola 64: 263-268.

Bonga JM (1982) Tissue culture techniques. In: Bonga JM and Durzan D (eds.) Tissue culture in forestry. $2^{\text {nd }}$ ed., Martinus Nijhoff, Dordrecht, p. 4-35.

Bussmann RW, Malca G, Glenn A, Sharon D, Nilsen B, Parris B, Dubose D, Ruiz D, Saleda J, Martinez M, Carillo L, Walker K, Kuhlman A and Townesmith A (2011) Toxicity of medicinal plants used in traditional medicine in North Peru. Journal of Ethnopharmacology 137: $121-140$.

Calixto JB, Nicolau M and Yunes RA (1985) The selective antagonism of bradykinin action on rat isolated uterus by crude Mandevilla velutina extract. British Journal of Pharmacology 85: 729-731.
Cordeiro SZ, Simas NK, Henriques AB, Lage CLS and Sato A (2012) Micropropagation of Mandevilla moricandiana (A.DC.) Woodson. In vitro Cellular and Developmental Biology - Plant 48: 620-626.

Dell B and Huang L (1997) Physiological response of plants to low boron. Plant Soil 193: 103-120.

EPO - European Patent Office (2013) Patents database: Mandevilla. Available at $<$ http://ep.espacenet.com $>$ Accessed on Feb 12, 2013.

Grattapaglia D and Machado MA (1998) Micropropagação. In Torres AC, Caldas LS and Buso JA (eds.) Cultura de tecidos e transformação genética de plantas. Vol 1, CBAB/EMBRAPA, Brasília, p. 183-260.

Guerra MP, Torres AC and Teixeira JB (1999) Embriogênese somática e sementes sintéticas. In Torres AC, Caldas LS and Buso JA (eds.) Cultura de tecidos e transformação genética de plantas. Vol 2, CBAB/EMBRAPA, Brasília, p. 533-568.

Handro W, Floh EIS, Ferreira CM and Guerra MP (1988) Tissue, cell culture and micropropagation of Mandevilla velutina, a natural source of a bradykinin antagonist. Plant Cell Reports 7: 564-566.

Linsmaier EM and Skoog FA (1965) Organic growth factor requirements of tobacco tissue cultures. Physiologia Plantarum 18: 100-127.

Lloyd GB and McCown BH (1980) Commercially feasible micropropagation of mountain laurel (Kalmia latifolia) by use of shoot tip culture. Combined Proceedings, International Plant Propagators' Society 30: 421-427.

Murashige T and Skoog FA (1962) Revised medium for rapid growth and bioassays with tobacco tissue cultures. Physiologia Plantarum 15: 473-497.

Pereira-Netto AB (1996) In vitro propagation of Hancornia speciosa, a tropical fruit-tree. In vitro Cellular and Developmental Biology - 
Plant 32: 253-256.

Pilatti FK, Aguiar T, Simões T, Benson EE and Viana AM (2011) In vitro and cryogenic preservation of plant biodiversity in Brazil. In vitro Cellular and Developmental Biology - Plant 47: 82-98.

Raha S and Roy SC (2001) In vitro plant regeneration in Holarrhena antidysenterica Wall., through high-frequency axillary shoot proliferation. In vitro Cellular and Developmental Biology - Plant 37: $232-236$.

Sahai A, Shahzad A and Sharma S (2010) Histology of organogenesis and somatic embryogenesis in excised root cultures of an endangered species Tylophora indica (Asclepiadaceae). Australian Journal of
Botany 58: 198-205.

Sales MF, Kinoshita LS and Simões AO (2006) Eight new species of Mandevilla Lindley (Apocynaceae, Apocynoideae) from Brazil. Novon 16: 112-128.

Schultes RE (1979) De plantis toxicariis e mundo novo tropicale comentationes. XIX. Biodynamic Apocynaceous plants of the northwest Amazon. Journal of Ethnopharmacology 1: 165-192.

Sudha CG and Seeni S (2006) Spontaneous somatic embryogenesis on in vitro root segment cultures of Rauvolfia micrantha Hook. f. - A rare medicinal plant. In vitro Cellular and Developmental Biology - Plant 42: 119-123. 